\title{
Stability Of Money Demand In A Developing Economy: Empirical Evidence From South Africa
}

Ferdinand Niyimbanira, PhD Candidate, Vaal University of Technology, South Africa

\begin{abstract}
A stable money demand function plays a vital role in the analysis of macroeconomics, especially in the planning and implementation of monetary policy. When investigating the theory of money demand, there are some important issues that need to be considered, such as the choice of the appropriate measure of money, the scale variable (income or wealth) and the opportunity cost variable (short- or long-term interest rates). This paper estimates a stable long-run equilibrium relationship between real money demand (RM2) and its explanatory variables in South Africa, using cointegration and error correction methods. The results obtained confirm the existence of such stable equilibrium relationships. The crucial results from the Error Correction model (ECM) indicate that monetary policy in South Africa is effective. However, in spite of its efficiency, monetary policy does not have a quick effect, needing at least four quarters (one year) from its inception to make a real difference. In other words, there might be difficulties in implementing monetary policy in an emergency situation. Policy implications and suggestions for future research are made in the paper.
\end{abstract}

Keywords: Money Demand Stability; South Africa; Monetary Policy

\section{INTRODUCTION}

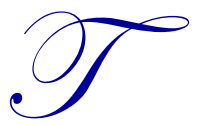

heoretically and empirically, the equilibrium relationship between the demand for money and its explanatory variables plays an important role in macroeconomic models. The aim of this paper is to investigate the significance of the long-run relationship of real money demand (RM2) and its determinants, in the context of South Africa. The fundamental issues are: 1) what are the determinants of money demand and 2) how can one determine whether this relationship does or does not exist? The relationship between money demand and its explanatory variables must be assumed when one estimates a money demand function or analyses its applications (Miyao, 1996). This assumption is supported by Feldstein and Stock (1992) and Konishi, Ramey and Granger (1993), who demonstrate, and confirm, that real money demand plays a key role in the analysis of real economic activities.

The most recently used method for examining long-run equilibria of money demand is the cointegration technique. Many researchers including the giants in the field of money demand (for example, Hafer and Jansen, 1991, Miller, 1991 and Friedman and Kuttner, 1992) used this technique and found long run equilibrium between real money demand and its explanatory variables. However, this long-run relationship may vary from country to country. In the empirical analysis, after knowing whether the series are stationary or not, the cointegration test is the next step. Before estimating an economic model one might first-difference the time series, due to the fact that most of macroeconomic series are non-stationary. But according to Hafer and Jansen (1991), this can remove much of the long-run characteristics of the data. However, Engle and Granger (1987) noted that, even though most macroeconomic series are non-stationary, economic theory often provides a rationale why certain variables should obey certain equilibrium constraints. It is the meeting of these equilibrium constraints that serves as a measure of stability: a critical aim of this paper. 
Many studies, such as Friedman (1959), Meltzer (1963) and Laidler (1966), have provided generally satisfactory results, in the sense that results match the general theory of money demand. However, this literature is criticised by Courchene and Shapiro (1964), who identified certain dynamic problems with it, such as difficulties with autocorrelation and the once-lagged money stock possesses a significant role. According to Miller (1991), a distinction between the long-run and short-run demand for money should be made. Chow (1966) argues that shortrun money demand adjusts slowly toward long-run equilibrium. For Miller (1991, p.139), "this stock-adjustment specification has weathered significant storms and remains the centerpiece of many money demand studies." If the expectation of the existence of the long-run equilibrium is met, the last step is to use the Error Correction Mechanism (ECM) test to estimate the short-run dynamic adjustment equation which identifies how changes in the money stock responds to changes in the determinants of long-run money demand (Handa, 2000). Hence, this paper uses cointegration and ECM to investigate the equilibrium relationship between the demand for money and its explanatory variables in South Africa.

\section{THE DATA AND SPECIFICATION OF THE MODEL}

According to Baumol (1952), Tobin (1956) and Friedman (1956), money is held because it is used as an inventory to smooth differences between income and expenditure streams, and as one among several assets in a portfolio. For Ericsson and Sharma (1996) the transaction motive implies that nominal money demand depends on the price level and some measure of the volume of the real transactions. Holdings of money as an asset are determined by the return to money, as well as returns on alternative assets, and by total assets (often proxied by income). The present study investigates empirically the impacts of determinants such as income and an interest rate on the demand for money (RM2). It is believed that the demand for money is likely to depend upon the exchange rate and inflation rate, in addition to the interest rate and the level of income (Handa, 2000). Thus, the model used in this paper is explicitly written as following:

$\ln R M 2_{t}=\beta_{1}+\beta_{2} \ln Y_{t}+\beta_{3} \ln R_{t}+\beta_{4} \ln \pi_{t}+\beta_{5} \ln \mathrm{E} R_{t}+u_{t}$

Where RM2 stands for real money demand, $\beta_{1}$ is the intercept term, $\beta_{2}, \beta_{3}, \beta_{4}$ and $\beta_{5}$ are the slope coefficients of the explanatory variables, $Y$ is real income, $R$ is the Treasury-Bill rate, $\pi$ is the inflation rate and $E R$ stands for the exchange rate; while $u_{t}$ is the usual error term and $t$ is time. This paper employed quarterly data for the period 1990 to 2007 (69 observations). RM2 is used as a measure of real money stock. To obtain RM2 the monetary aggregate (M2) was multiplied by gross domestic expenditure (in constant 2000 prices) and divide this result by the Gross Domestic Expenditure (in current 2000 prices). Gross Domestic Expenditure (in constant 2000 prices) is used as the real income $(Y)$ variable and is also known as the scale variable. For the opportunity cost variables of holding money, the Treasury-Bill rate for 91 days is used as the interest rate (R). In contrast with existing studies on the subject, the present paper includes the inflation rate $(\pi)$ and the exchange rate (ER) in the model. For Ramanathan (1995) the logarithmic function is closely related to the concept of elasticity used in economics and econometrics. As elasticities are critical in applied economics, it is convenient to have a constant elasticity model and the logarithmic function gives such a model (Wooldridge, 2000). Therefore, all variables used in this study are in their natural logarithmic forms.

\section{METHOD APPLICATIONS, RESULTS AND DISCUSSION}

As a general rule, non-stationary time variables must not be used in a regression model, in order to avoid the problem of spurious regression (Hill et al., 2001). In a case where two or more variables share similar stochastic trends, they are said to be cointegrated if a linear combination of them is stationary. A cointegrating relationship may be seen as a long-term or equilibrium phenomenon, since it is possible that cointegrating variables may deviate from their relationship in the short run, but their association would return to equilibrium ones in the long run (Brooks, 2002). This study uses the Augmented Engle-Granger (AEG) test and the Cointegrating Regression Durbin-Watson (CRWD) test. To illustrate these tests we first obtain the regression from estimating equation 1, and regressing RM2 on $\mathrm{Y}, \mathrm{R}, \pi$ and $\mathrm{ER}$ in natural logarithmic form, obtaining the following results: 


$$
\begin{aligned}
& \ln R M 2_{t}=-4.953+1.5289 Y_{t}-0.002 R_{t}+0.003 \ln \pi_{t}-0.193 \ln E R_{t} \\
& \begin{array}{llllll}
\mathbf{S E} & (1.267) & (0.086) & (0.004) & (0.03) & (0.075)
\end{array} \\
& \mathrm{Tau}=(-3.908) \quad(17.79) \quad(-0.394) \quad(0.096) \quad(-2.564)
\end{aligned}
$$

$\mathrm{R}^{2}=0.945 ;$ Adj. $\mathrm{R}^{2}=0.941 ; \mathrm{DW}=0.814 ; \mathrm{F}=272.405 ;$ Standard error of estimate $=0.064$

From the results in equation 2, the F- statistic is very high, which means that the model as a whole is statistically significant. Except for $\ln \pi$, other estimated coefficients have the expected signs. The computed $\tau$ (tau) statistic for Y (17.79) is highly statistically significant (at which level of significance) and the computed $\tau$ for the exchange rate value $(-2.564)$ is also statistically significant at 5 percent. But the computed $\tau$ for the interest rate and the inflation rate variables, as defined, are not statistically significant. This confirms analysis by Todani (2007), that "the long-run link between money and inflation is rather weak." This means that both the interest rate and the inflation rate do not have a statistical influence on the money demand in South Africa. It agrees with Contogiannis and Shahi (1982) who showed that the interest rate included in their model was not found to be not statistically significant. This might support neoclassical theory concerning the neutrality of money, where the impact of high growth in the money stock results in a similar increase in the inflation rate. Empirical evidence reviewed by Handa (2000) suggests that money can be neutral in some cases and non-neutral in others. Although the present results show that money might be neutral in the long-run equilibrium for South African data, Handa (2000, p.493) pointed out that this long-run neutrality operates only in a simple exchange economy with commodities and money but not in a more complex economy where consumers base consumption decisions on the permanent income hypothesis. But these are spurious results as explained below.

The $\mathrm{R}^{2}$ from equation 2 is high, which shows a good fit for the variation in the dependent variable (RM2). In other words, there is some link between money demand and the determinants, but Miller (1991) stresses that a high $\mathrm{R}^{2}$ may only indicate correlated trends and not true economic relationships. The computed Durbin-Watson (DW) value for equation 2 is very low, indicating that the model has a problem of autocorrelation. This might be because some of the time series are non-stationary. One may strongly suspect that the estimated regression is spurious due to RM2 and exchange rate variables, which are individually non-stationary at the 5 percent level of significance, while the explanatory variables are stationary at this significance level. A good rule of thumb for one having a spurious regression is when the $\mathrm{R}^{2}>\mathrm{DW}$, which is indeed the case here.

The results show that intercept is statistically significant. The inflation rate has a positive sign while the other variables do meet the traditional expectations. The insignificance of the interest rate elasticity coefficient, while surprising, is not different from other studies on the demand for money in South Africa, (see, for example, Stadler, 1981; Contogiannis \& Shahi, 1982 and Whittaker, 1985). This is also confirmed by Fair (1987) who found four out of 27 equations have the wrong sign for the interest rate, namely those for Sweden, South Africa, India and the Philippines. Compared to Todani's (2007) study, the income elasticity obtained here (1.4488), shown in Table 1, is not much higher than unity, as expected from theory of money demand (see Friedman, 1959; and Friedman and Schwartz, 1982). These results agree with Feige (1967), who found an estimated income elasticity of 1.3. Our income elasticity result says that, in the long-run, a one percent increase in income leads to an increase of 1.4488 percent in the real quantity of money demanded. These results also agree with Handa (2000), who believes that the income elasticity of RM2 can be theoretically justified to be unity or greater. However, this differs from Goldfeld (1973), who found that the long-run income elasticity of M2 is huge 2.3, but the interest rate elasticity does not fall in the usual range of -0.15 to -0.50 , posited by Handa (2000) (see Friedman, 1959; and Friedman and Schwartz, 1982). Table 1 shows all the long-run elasticities.

Table1. Long-run Elasticities for Equation 2

\begin{tabular}{|l|c|}
\hline \multicolumn{1}{|c|}{ Variable } & Elasticities \\
\hline $\ln \mathrm{Y}$ & 1.4488 \\
\hline $\mathrm{R}$ & -0.0013 \\
\hline $\ln \pi$ & 0.0005 \\
\hline $\ln \mathrm{ER}$ & -0.0695 \\
\hline
\end{tabular}


According to Engle and Granger (1987), cointegration analysis confronts the problem of a spurious regression by identifying conditions in an equation for which a relationship might have some economic meaning. To find whether or not the regression (2) is not spurious, the Augmented Engle-Granger test was performed by investigating whether or not the data contains a unit root using residuals from equation (2) using the Augmented Engle-Granger test to see if these results are robust.

\section{Augmented Engle-Granger (AEG) Test}

A cointegration regression is run by estimating the augmented DF regression. The lagged error term and a change in that variable are included. The following are the results from the AEG estimation:

$\Delta \hat{U}_{t}=-0.008+0 t-0.486 \hat{U}_{t-1}+0.389 \Delta \hat{U}_{t-1}$

$\mathrm{Tau}=(-0.700)(0787)(\mathbf{- 5 . 2 3 8}) \quad(3.889)$

$\mathrm{R}^{2}=0.359 \quad$ Adj. $\mathrm{R}^{2}=0.329 \quad \mathrm{DW}=1.792 \quad \mathrm{~F}=11.943$

The absolute value of the computed tau value of $\hat{U_{t-1}}(|-5.238|)$ is greater than the absolute critical value at 5 percent of significance level (-4.35). One does fail to reject the null hypothesis that cointegration exists between RM2 and its explanatory variables. These results reveal that all variables in one model, despite two initially being individually non-stationary, are cointegrated. This leads to the conclusion that the estimated econometric model (equation 1) represents the long-run money demand and is a candidate for examination of stability. This concurs with other South African studies on the cointegration test, such as those of Hurn and Muscatelli (1992), Moll (2000) and Nell (2003). These results are similar to those of Wasso (2002) and Ziramba (2007), who used the results of bounds testing to confirm the presence of a long-run equilibrium relationship between the demand for real money (RM2) and its determinants. This stability of money demand in South Africa is confirmed by Tavlas (1989), who uses the buffer stock or disequilibrium money market model.

\section{Cointegrating Regression Durbin-Watson test (CRDW)}

There are a number of alternative tests for cointegration. The simplest and quickest method, when one wants to find out if dependent and independent variables are cointegrated, is the cointegration regression DurbinWatson (CRDW) test proposed by Sargan and Bhargava (1983). According to Harris (1995), this is known to be the uniformly most powerful and invariant test of the null hypothesis of no cointegration. The null hypothesis is that there is a unit root in the potentially cointegrating regression residuals, while with the alternative, the residuals are stationary (Brook, 2007). This is based on the standard DW statistic obtained from equation 2. A comparison shows, the computed Durbin-Watson of 0.814 (from equation 2) is greater than the given critical values of 0.511; 0.386 and 0.322 at the 1,5 and 10 percent significance levels, respectively. In this case, one does not fail to reject the null hypothesis of no cointegration, as for the previous method and it is concluded that RM2 and its explanatory variables are cointegrated. Hence it shows a meaningful relationship between the variables (Banerjee, Dolado, Hendry and Smith, 1986). This conclusion remains the same even if one compares the computed DW with the one suggested by Sargan and Bhargava (1983) for a money-demand model, whose critical value for rejecting the null hypothesis of no cointegration is 0.48 .

\section{Error Correction Mechanism}

The estimation of money demand has a rich tradition, as it has been calculated in many countries. Initial studies by Friedman (1959), Meltzer (1963) and Laidler (1966) found satisfactory results, in the sense that the observed results matched theoretical priors. Courchene and Shapiro (1964) identify certain issues such as autocorrelation and lagged money stock effects which could play an important role. According to Miller (1991), a distinction between the long-run and short-run demand for money should be made. Chow (1966, p.115) states that "short-run money demand adjusted slowly toward long-run equilibrium; this stock-adjustment specification has weathered significant storms and remains the centerpiece of many money demand studies." It is possible that when economic theory posits a long run equilibrium function for a variable, in the short-run disequilibrium may occur. 
The cointegration technique captures the long-run relationship between the dependent and explanatory variables, but does not capture the dynamic response of the former to changes in the latter. To correct for these disequilibrium issues, the Error Correction Mechanism (ECM) is introduced to estimate how the observed model moves towards the long-run equilibrium whenever it has been pushed away (Engle and Granger, 1987, p.251). The results of the ECM (based on Wooldridge (2000, p.592) are shown below:

$$
\begin{aligned}
& \Delta \ln R M 2_{t}=0.008+0.317 \Delta \ln Y_{t}-0.012 \Delta R_{t}-0.021 \Delta \ln \pi_{t}-0.061 \Delta \ln E R_{t}-0.20 \hat{U}_{t-1} \\
& \text { t-values } \quad(3.296)(3.073) \quad(-0.33) \quad(-0.89) \quad(-0.79) \quad(-3.43)
\end{aligned}
$$$$
\mathrm{R}^{2}=0.222 ; \text { Adj. } \mathrm{R}^{2}=0.1599 ; \mathrm{DW}=1.939 ; \mathrm{F}=4.459
$$

According to Engle and Granger (1987, p.254), "the error correction coefficient should be negative and statistically significant in order to guarantee that the divergences, which occur in one period, are corrected in the next period." The results show the coefficient of the equilibrium error term $\left(U_{t-1}\right)$ is negative, as expected, and statistically significantly different from zero, implies that 0.20 of the discrepancy between money demand and its explanatory variables, for this paper, in the previous quarter is eliminated in the following quarter. This value of 0.20 shows that there is the possibility for the monetary policy committee to anticipate changes when making policy recommendations. These results of the error correction method are not too far from those of Reinhardt (1998), Moll (2000) and Tlelima and Turner (2004). When using Ayto's (1989) half-life formula $\left(\frac{\ln 0.5}{0.20}=3.47\right)$, half the adjustment will be reached after four quarters (3.47). This speed of adjustment for money demand suggests that the money market in South Africa needs about four quarters to re-adjust to equilibrium. This is also checked by Monte Carlo simulation of equation 4 with 200 repeated random samples. Simulations with fatter tailed distributions suggest the estimate of approximately four quarters is on upper limit. This means that in about four quarters, roughly half of the excess demand in the money demand market corrects itself. The implication of this negative error correction term for the demand for real money is observed when the real level of the money stock is at disequilibrium. For example, if real money demand is too high in relation to the explanatory variables, the negative value of the error term would cause a downwards adjustment in the level of the money stock to occur in subsequent periods in order to correct for the disequilibrating error. The "speed of adjustment" calculation shows, and is a core result of this paper, that the adjustment to equilibrium is found to be four quarters. The equilibrium error is corrected by appropriate adjustments that tie the short-run behaviour of RM2 to its long-run value. These results agree with those of Ericsson and Sharma (1996), Moll (2000) and Sayinzoga (2005), who found error correction coefficients of $-0.127,-0.14$ and -0.12 , respectively although for different time period and countries. When using the estimated standard error (0.028) to calculate the variance, the results obtained with usage of the half-life formula (Ayto, 1989) are a range of a lower and upper tail of approximately two and eight quarters, respectively, in which four quarters falls in the middle of this range. See Figure 1 below:

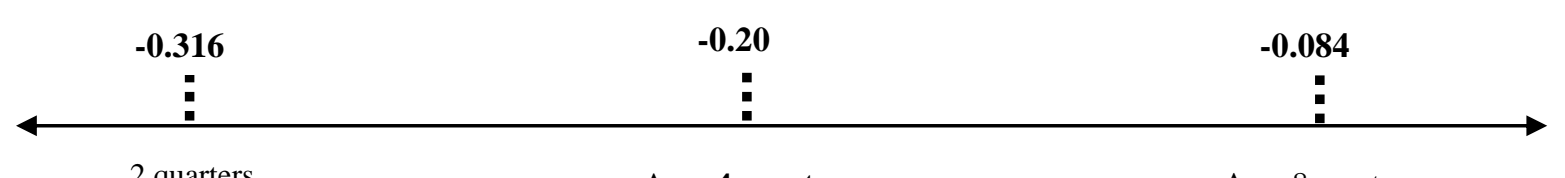

Figure 1: Variance of the half life of the error adjustment.

This means that the speed of adjustment for money demand in South Africa, which is equal to 0.20, is low. However, the results in this paper results differ from those of Jean-Claude (2001) and George (2002), who found an error correction coefficient of -0.3 for Cameroon and 2.5 Uganda, respectively. The Durbin-Watson and F-statistic obtained show that the explanatory variables are statistically significant at the 5 percent level of significance. The value of the Durbin-Watson test (1.939) for the cointegration regression demonstrates that a spurious regression is unlikely. This is because the null hypothesis of a unit root in the errors, or CRDW $\approx 0$, is rejected, due to the 
calculated value of 1.939 being larger than the relevant critical value of 0.5 (Brooks, 2002). The short-run income coefficient obtained (0.3) is closer to the value predicted by Miller and Orr (1968) than to the one expected by general theory. A pleasing result is that the observed signs for the interest rate and inflation rate variable are as expected. It is surprising that the absolute value of the effect is 0.012 for both variables. It should be noted that, as the exchange rate depreciates and the demand for domestic currency falls; the effect for the exchange variable is 0.06 .

\section{CONCLUSION}

The main aim of this paper was to investigate the stability of the long-run relationship between money demand and its determinants in South Africa. Three tests were conducted: Augmented Engel-Granger, a Cointegration Regression Durbin-Watson test and the Error Correction Mechanism test. All these three tests support the presence of a long-run relationship between RM2, real income, the interest rate, the rate of inflation and the exchange rate in South Africa and are consistent with research conducted in other countries. The estimated elasticities for income and inflation rate agree with the literature (Handa, 2000). The error correction coefficient for

$\hat{U_{t-1}}(-0.20)$ from the error correction model indicates that disequilibrium in the money market can last for up to four quarters and agrees with how South African Reserve Bank views its own policy impact, and Monte Carlo simulations of this specification with data drawn from distribution other than the normal. In general, this paper presents evidence indicating that policy changes by monetary authority in South Africa have an impact on the economy and such impact last for one year. A topic for future research is to investigate how the new monetary policy authorities (who take over in an environment of missed inflation targets) can work with other new policy makers on fiscal matters in order to devise solutions to emergency situations in world markets that have been impacting upon South Africa.

\section{AUTHOR INFORMATION}

Ferdinand Niyimbanira, PhD Candidate, Lecturer in Economics, Faculty of Management Sciences, Vaal University of Technology, Private Bag X021, Vanderbijlpark, 1900, South Africa. E-mail: ferdinandn@vut.ac.za

\section{REFERENCES}

1. Ayto, J. (1989). 20th Century Words. Cambridge, Cambridge University Press.

2. Banerjee, A., Dolado, J., Hendry, D. and Smith, G. (1986). Exploring Equilibrium Relationships in Econometrics through Static Models: Some Monte Carlo Evidence. Oxford Bulletin of Economics and Statistics, 48(3), 253-277.

3. Baumol, W. J. (1952). The Transactions Demand for Cash: an Inventory Theoretical Approach. Quarterly Journal of Economics, 66, 545-556.

4. Brooks, C. (2002). Introductory Econometrics for Finance. Cambridge, Cambridge University Press.

5. Chow, G. C. (1966). On the Long-run and Short-run Demand for Money. Journal of Political Economy, 74, 111-131.

6. Contogiannis, E. and Shahi, M. A. (1982). The Demand for Money and Inflationary Expectations in South Africa. South African Journal of Economics, 52(1), 1-41.

7. Courchene, T. J. and Shapiro, H. T. (1964). Money Supply and Money Demand: An Econometric Analysis for Canada. Journal of Political Economy, 4(10), 498-503.

8. Engle, R. F. and Granger, C.W.J. (1987). Co-integration and Error Corrections: Representation, Estimation and Testing. Econometrica, 55(2), 251-276.

9. Ericsson, N. R. and Sharma, S. (1996). Broad Money Demand and Financial Liberalisation in Greece. International Discussion Paper 559, Board of Governors of the Federal Reserve System (U.S) 1-51.

10. Fair, R. C. (1987). International Evidence on the Demand for Money. Review of Economics and Statistics, 69, 473-490.

11. Feige, E. L. (1967). Expectations and Adjustments in the Monetary Sector. American Economic Review, $57,462-473$. 
12. Feldstein, M. and Stock, J. H. (1992). The use of Monetary aggregate to Target Nominal GDP. National Bureau of Economic Research working Paper, No. 4304.

13. Friedman, M. and Kutter, K. N. (1992). Money, Income, Prices and Interest Rates. American Economic Review, 82, 51-72.

14. Friedman, M. (1956). The Quantity Theory of Money: A Restatement. Studies in the Quantity of Money. In Readings in Macroeconomics by Mueller, M.G. Reprinted from Chicago, University of Chicago Press, 3-21.

15. Friedman, M. (1957). A Theory of the Consumption Function. Princeton University Press.

16. Friedman, M. (1959). The Demand for Money: Some Theoretical and Empirical Results. Journal of Political Economy 67(6), 327-351.

17. Friedman, M. and Kuttner, K. N. (1992). Money, Income, Prices, and Interest Rates. American Economic Review, 82, 472-492.

18. Friedman, M. and Schwartz, A. J. (1982). Monetary Trend in the United States and the United Kingdom: Their relation to Income, Prices and Interest Rates, 1867-1975. Chicago, University of Chicago Press.

19. George, K. (2002). Evidence on the Demand for Money Function in Uganda. Economics Working Paper Archive at WUSTL. Retrieved from: http://Econwpa.wustl.edu:80/eps/dev/papers/0210/0210005.pdf

20. Goldfeld, S. M. (1973). The Demand for Money Revisited. Brookings Papers on Economic Activity, 3, 577-638.

21. Hafer, R. W and Jansen, D. W. (1991). The Demand for Money in the United States: Evidence from Cointegration Tests. Journal of Money, Credit, and Banking, 23, 155-168.

22. Handa, J. (2000). Monetary Economics. New York, Routledge.

23. Harris, R. (1995). Using Cointegration Analysis in Econometric Modelling. London, Prentice Hall/Harvester Wheatsheaf.

24. Hill, R. C, Griffiths, W. E. and Judge, G. G. (2001). Undergraduate Econometrics. $2^{\text {nd }}$ Edition. America, John Wiley \& Sons, Inc.

25. Hurn, A. S. and Muscatelli, V. A. (1992). The Long-run Properties of Demand for M3 in South Africa. South African Journal of Economics, 60(2), 158-172.

26. Jean-Claude, N. (2001). A Cointegration Analysis of Broad Money Demand in Cameroon. IMF Working Paper WP/01/26, IMF.

27. Konishi, T., Ramey, V. A. and Granger, C. W. J. (1993). Stochastic Trends and Short-run Relationship between Financial Variables and Real Activity. National Bureau of Economic Research working Paper, No. 4275.

28. Laidler, D. E. W. (1966). The Rate of Interest and the Demand for Money-Some Empirical Evidence. Journal of Political Economy, 74(12), 545-555.

29. Meltzer, A. H. (1963). The Demand for Money: The Evidence from the Time Series. Journal of Political Economy, 71 (6), 219-246.

30. Miller, S. M. (1991). Monetary Dynamics: An Application of Cointegration and Error-correction Modeling. Journal of Money, Credit, and Banking, 23, 139-154.

31. Miller, M. H. and Orr, D. (1968). The Demand for Money by Firms: Extensions of Analytical Results. The Journal of Finance, 23(5), 735-759.

32. Miyao, R. (1996). Does a Cointegrating M2 Demand Relation Really Exist in Japan? Journal of the Japanese and International Economies, 10, 169-180.

33. Moll, P. G. (2000). The Demand for Money in South Africa: Parameter Stability and Predictive Capacity. The South African Journal of Economics, 68(2), 190-208.

34. Nell, K. S. (2003). The Stability of M3 Money Demand and Monetary Growth Targets: The Case of South Africa. Journal of Development Studies, 39(3), 233-252.

35. Ramanathan, R. (1995). Introductory Econometrics: with Applications. $3^{\text {rd }}$ Edition. New York, The Dryden Press.

36. Reinhardt, A. M. (1998). An Estimation of the Demand for Real Money in South Africa, with the Application of Cointegration and Error Correction Modelling over the Period 1965:2 to 1996:4. Unpublished Masters Thesis.

37. Roley, V. V. (1985). The Response of Short-Term Interest Rates to Weekly Money Announcements: Reply. Journal of Money, Credit, and Banking, 17(2), 271-273. 
38. Sargan, J. D. (1984). Wages and Prices in the United Kingdom: A study in Econometric Methodology. Originally Published in 1964 and Reproduced in Wallis K.F and Hundry D. F eds., Quantitative Economics and Econometric Analysis, Oxford, Basil Blackwell.

39. Sargan, J. D. and Bhargava, A. S. (1983). Testing Residuals from Least Squares Regression for Being Generated by the Gaussian Random Walk. Econometrica, 51, 153-174.

40. Sayinzoga, A. (2005). An Analysis of Money Demand Stability in Rwanda. Unpublished Masters thesis.

41. Stadler, G. (1981). The Demand for Money in South Africa. South African Journal of Economics, 49(2), 145-152.

42. Tavlas, G. S. (1989). The Demand for Money in South Africa: a Test of the Buffer Stock Model. South African Journal of Economics, 57(1), 1-13.

43. Tlelima, T. and Turner, P. (2004). The Demand for Money in South Africa: Specification and Tests for Instability. South African Journal of Economics, 72(2), 25-36.

44. Tobin, J. (1956). The Interest Elasticity of Transactions Demand for Cash. Review of Economics and Statistics, 38, 241-247.

45. Todani, K. R. (2005, February). A Cointegrated VAL Model of M3 demand in South Africa. South African Reserve Bank, Department, Unpublished Paper.

46. Wasso, G. R. (2002, November). Broad Money Demand and Financial Liberalisation in South Africa. South African Reserve Bank, Occasional Paper No. 18.

47. Whittaker, J. (1985). The Demand for Money in South Africa: Towards a More Accurate Perspective. South African Journal of Economics, 53(2), 184-196.

48. Wooldridge, J. M. (2000). Introductory Econometrics: A Modern Approach. Canada, South-Western College Publishing.

49. Ziramba, E. (2007). Demand for Money and Expenditure Components in South Africa: Assessment from Unrestricted Error-Correction Models. South African Journal of Economics, 75(3), 412-424. 